\title{
Endoscopic ultrasonography and somatostatin receptor scintigraphy in the preoperative localisation of insulinomas and gastrinomas
}

T Zimmer, U Stölzel, M Bäder, K Koppenhagen, B Hamm, H Buhr, E-O Riecken, B Wiedenmann

\begin{abstract}
Background-Endoscopic ultrasonography (EUS) and somatostatin receptor scintigraphy (SRS) can detect a high percentage of gastroenteropancreatic neuroendocrine tumours especially in the upper gastrointestinal tract. The ability of these procedures to localise primary tumour lesions and metastases of gastrinomas and insulinomas was evaluated in comparison with transabdominal ultrasonography (US), computed tomography (CT) and magnetic resonance imaging (MRI) .

Patients and Methods-In a prospective trial, patients with gastrinomas $(n=10)$ and insulinomas $(n=10)$ diagnosed by clinical signs and laboratory tests were assessed by EUS, SRS, US, CT and MRI.

Results-In 10 patients with gastrinoma and 10 patients with insulinoma, a total of 14 separate primary tumour lesions were histologically confirmed for each of the tumour entities. The mean diameter was $2.1 \mathrm{~cm}$ for gastrinomas and $1.5 \mathrm{~cm}$ for insulinomas. All insulinomas and nine gastrinoma lesions were located in the pancreas. Three gastrinomas were found in the duodenal wall, one in a periduodenal lymph node, and one in the liver. For gastrinomas, sensitivities were $79 \%$ with EUS, 86\% with SRS and $29 \%$ with CT, US, and MRI. For insulinomas, sensitivities were $93 \%$ with EUS, $14 \%$ with SRS, $21 \%$ with CT and $7 \%$ with US and MRI.

Conclusions-EUS is of high value for localising primary lesions of both tumour entities. SRS is a very sensitive procedure for diagnosing of gastrinomas but not insulinomas. CT, US and MRI are primarily useful for visualising metastases.

(Gut 1996; 39: 562-568)
\end{abstract}

Keywords: somatostatin receptor scintigraphy, endoscopic ultrasonography, insulinoma, gastrinoma.

Insulinomas and gastrinomas, defined as functional neuroendocrine tumours of the upper gastrointestinal tract, become clinically manifest by characteristic symptoms and are confirmed by specific laboratory tests (fasting test, secretin test). The treatment of choice is surgical removal of the tumour. ${ }^{12}$ It is difficult to preoperatively localise the primary tumour or to determine the extent of the disease, especially lymph node involvement and distant metastases. Preoperative localisation with noninvasive imaging techniques such as computed tomography (CT), transabdominal ultrasound (US) and magnetic resonance imaging (MRI) is only successful in $30-60 \%$ of cases. ${ }^{3-5}$ In particular, tumours smaller than $2 \mathrm{~cm}$ in diameter and those located within the gastrointestinal wall escape detection in almost all cases. ${ }^{6}$ More invasive localisation procedures such as angiography, transhepatic portal venous blood sampling and exploratory laparotomy, including endoscopic transillumination and intraoperative ultrasound, have been successfully applied in over $90 \%$ of cases. ${ }^{7-10}$ The commonly benign insulinomas with mostly solitary and solely intrapancreatic occurrence are generally difficult to localise because they are usually less than $2 \mathrm{~cm}$ in size. ${ }^{11}$ Preoperative diagnostic assessment of gastrinomas is equally problematic. Gastrin secreting neuroendocrine tumours are extrapancreatic in $50 \%$ of cases, small - especially in the duodenal wall - often multilocular, and metastatic in about half of the cases. ${ }^{12}{ }^{13}$ Apart from localisation of the primary tumour, detection of local tumour infiltration, lymph node involvement, and metastases is of great importance before surgical removal.

Visualisation of the pancreas as well as the intestinal wall and its immediate surroundings can be achieved by endoscopic ultrasound (EUS) with very high resolution. Pathological structures up to $2-3 \mathrm{~mm}$ in size can be detected. Several mainly retrospective studies have shown that EUS is a highly sensitive imaging procedure for pancreatic endocrine tumours, detecting $80-90 \%$ of the lesions. ${ }^{14-17}$ Prospective studies also showed high sensitivities for EUS in the localisation of insulinomas and intrapancreatic gastrinomas, whereas extrapancreatic gastrinomas could be localised with lower sensitivities. ${ }^{18-21}$

Somatostatin receptor scintigraphy (SRS) is a new sensitive method for the detection of neuroendocrine tumours and their metastases. Tumour tissue carrying somatostatin receptors is scintigraphically detectable in vitro and in vivo with radioactively labelled pentetreotide, a synthetic somatostatin analogue. ${ }^{22}$ Neuroendocrine tumours of the small intestine and gastrinomas can be visualised with high sensitivity in $80-90 \%$ of cases. ${ }^{23-26}$ Thus the combination of EUS and SRS enhanced the success rate in localising gastrinomas preoperatively. ${ }^{21}$

At the time our study was started, most results had been obtained retrospectively and 
TABLE I Characteristics of patients with gastrinoma

\begin{tabular}{|c|c|c|c|c|c|c|c|}
\hline \multirow[t]{2}{*}{ Patient } & \multirow[t]{2}{*}{ Age } & \multirow[t]{2}{*}{ Sex } & \multirow[t]{2}{*}{ Symptoms } & \multicolumn{2}{|l|}{ Preoperative } & \multicolumn{2}{|l|}{ Postoperative } \\
\hline & & & & $\begin{array}{l}\text { Basal serum } \\
\text { Gastrin concentration } \\
(p g / m l)\end{array}$ & $\begin{array}{l}\text { Secretin test } \\
\text { Increase in } \\
\text { gastrin }(\mathrm{pg} / \mathrm{ml})\end{array}$ & $\begin{array}{l}\text { Basal serum } \\
\text { Gastrin concentration } \\
\text { (pg/ml) }\end{array}$ & $\begin{array}{l}\text { Secretin test } \\
\text { Increase in } \\
\text { gastrin }(p g / m l)\end{array}$ \\
\hline 1 & 74 & $\mathrm{~F}$ & Ulcer & 726 & 624 & 628 & 473 \\
\hline 2 & 42 & $\mathrm{~F}$ & Ulcer & 596 & 298 & 295 & 212 \\
\hline 3 & 8 & $\mathrm{~F}$ & Ulcer/Diarrhoea & 976 & 311 & 1123 & 476 \\
\hline 4 & 37 & $M$ & Ulcer & 98 & 412 & $<20$ & 246 \\
\hline 5 & 30 & $\mathrm{~F}$ & Ulcer & $\begin{array}{l}<20 \\
674\end{array}$ & $\begin{array}{l}246 \\
512\end{array}$ & $\begin{array}{r}<20 \\
96\end{array}$ & $\begin{array}{r}43 \\
131\end{array}$ \\
\hline 6 & 38 & $\mathrm{~F}$ & Ulcer & 1123 & 476 & $<20$ & 78 \\
\hline 7 & 62 & $M$ & Diarrhoea & 20 & 441 & $<20$ & 15 \\
\hline 8 & 80 & $\mathrm{~F}$ & Ulcer & 327 & 276 & 411 & 293 \\
\hline 9 & 60 & $\mathrm{M}$ & Ulcer & 236 & 448 & $<20$ & 78 \\
\hline 10 & 61 & $M$ & Ulcer & 142 & 327 & 134 & 53 \\
\hline
\end{tabular}

Normal serum gastrin value $<150 \mathrm{pg} / \mathrm{ml}$. Normal secretin test if increase of gastrin $<200 \mathrm{pg} / \mathrm{ml}$.

partly without comparison to surgical findings. Because a direct comparison between SRS and EUS was also lacking, we have carried out a prospective comparative study on the value of EUS, SRS, CT, US, and MRI in the diagnostic assessment of insulinomas and gastrinomas with reference to the final surgical findings.

\section{Methods}

Twenty patients (14 female, 6 male, mean age 52 (range 8-82) years) with insulinomas $(n=10)$ or gastrinomas $(n=10)$ were prospectively examined by EUS, SRS, US, CT, and MRI from March 1991 until December 1994 (Table I and II). All patients were screened for hyperparathyroidism by determination of

TABLE II Characteristics in patients with insulinoma

\begin{tabular}{|c|c|c|c|c|c|}
\hline \multirow[t]{2}{*}{ Patient } & \multirow[t]{2}{*}{ Age } & \multirow[t]{2}{*}{ Sex } & \multicolumn{2}{|l|}{ Preoperative } & \multirow{2}{*}{$\begin{array}{l}\text { Postoperative } \\
\text { hypoglycaemia }\end{array}$} \\
\hline & & & Hypoglycaemialfasting test & Insulin: glucose ratio & \\
\hline 1 & 41 & F & + & $1 \cdot 8$ & - \\
\hline 2 & 58 & $\mathrm{M}$ & + & $1 \cdot 4$ & - \\
\hline 3 (MEN I) & 38 & $\mathrm{~F}$ & + & 1.5 & - \\
\hline 4 & 65 & $\mathrm{~F}$ & + & $1 \cdot 6$ & - \\
\hline 5 & 54 & $\mathbf{F}$ & + & 1.9 & + \\
\hline 6 & 68 & $\mathbf{F}$ & + & $1 \cdot 8$ & + \\
\hline 7 & 43 & M & + & $1 \cdot 6$ & - \\
\hline 8 & 68 & $\mathbf{F}$ & + & $1 \cdot 5$ & - \\
\hline 9 & 70 & $\mathbf{F}$ & + & $1 \cdot 5$ & - \\
\hline 10 & 79 & $\mathrm{~F}$ & + & 3 & - \\
\hline
\end{tabular}

MEN I=Multiple endocrine neoplasia type I. serum calcium and parathyroid hormone concentrations and for pituitary tumour disease by determination of serum prolactin hormone concentrations. Results on primary tumour localisation have previously been reported in four patients with gastrinoma and four with insulinoma. ${ }^{6}$ The various imaging techniques were assessed for their value in localising tumours and their metastases. All investigations were carried out within four weeks and assessed by one or two experienced investigators.

In 10 patients, a gastrinoma was suspected because of recurrent ulcers $(n=9)$, diarrhoea $(n=2)$, increased basal gastrin values $(n=7)$, and a positive secretin test $(n=10)$ (Table $I)$. In 10 patients, an insulinoma was suspected on the basis of recurrent hypoglycaemia and a positive fasting test (Table II). In 10 of 10 patients with gastrinoma and eight of 10 patients with insulinoma, the diagnosis was confirmed histologically and immunohistologically after surgery (Tables III and V). Immunohistological examination was carried out with antibodies against chromogranin A, synaptophysin, neuron specific enolase, insulin, gastrin, somatostatin, and serotonin. In two of 10 patients with insulinoma the primary lesion was histologically confirmed by CT or US guided puncture (Table V). One female patient with insulinoma had a multiple endocrine neoplasia, type 1 (MEN I) (Table V).

TABLE III Surgical procedure and results of various imaging procedures in the preoperative localisation of gastrinomas

\begin{tabular}{|c|c|c|c|c|c|c|c|c|}
\hline \multirow{2}{*}{$\begin{array}{l}\text { Patient } \\
\text { No }\end{array}$} & \multirow{2}{*}{$\begin{array}{l}\text { Primary tumour } \\
\text { lesions }(n)\end{array}$} & \multirow{2}{*}{$\begin{array}{l}\text { Tumour } \\
\text { diameter }(\mathrm{cm})\end{array}$} & \multirow[t]{2}{*}{ Surgical results and procedures } & \multicolumn{5}{|c|}{ Localisation of primary tumour by } \\
\hline & & & & EUS & SRS & $C T$ & US & $M R I$ \\
\hline \multirow[t]{2}{*}{1} & \multirow[t]{2}{*}{2} & 4 & $\begin{array}{l}\text { Ph with portal vein infiltration } \\
\text { No resection }\end{array}$ & + & + & + & + & + \\
\hline & & 1 & D I, resection & + & + & - & - & - \\
\hline 2 & 1 & 3 & Solitary liver lesion, resection & + & + & + & + & + \\
\hline $3^{\star}$ & 1 & 4 & D IV, resection & - & + & - & - & - \\
\hline $4 \dagger$ & 1 & 6 & $\mathrm{Ph}$, Whipple operation & + & + & + & + & + \\
\hline \multirow[t]{2}{*}{5} & \multirow[t]{2}{*}{2} & 1.5 & $\mathrm{Pt}$, Whipple operation & + & + & - & - & - \\
\hline & & 1.5 & $\mathrm{Ph}$, Whipple operation & + & + & - & - & - \\
\hline \multirow[t]{2}{*}{6} & \multirow[t]{2}{*}{2} & 1.5 & $\mathrm{Ph}$, Whipple operation & + & + & - & - & - \\
\hline & & $1 \cdot 0$ & $\mathrm{Ph}$, Whipple operation & + & + & - & - & - \\
\hline 7 & 1 & 0.8 & D I, enucleation & + & + & - & - & - \\
\hline \multirow[t]{2}{*}{8} & \multirow[t]{2}{*}{2} & $2 \cdot 4$ & $\begin{array}{l}\text { Ph with mesenteric vein infiltration } \\
\text { No resection }\end{array}$ & - & + & + & + & + \\
\hline & & $0 \cdot 7$ & $\mathrm{~Pb}$, no resection & + & + & - & - & - \\
\hline 9 & 1 & 0.5 & $\mathrm{Ph}$, enucleation & + & - & - & - & - \\
\hline 10 & 1 & $1 \cdot 2$ & Lymph node, resection & - & - & - & - & - \\
\hline
\end{tabular}

$\mathrm{Ph}=$ pancreatic head tumour; $\mathrm{Pb}=$ pancreatic body tumour; $\mathrm{Pt}=$ pancreatic tail tumour; $\mathrm{D} \mathrm{I}-\mathrm{IV}=$ duodenal tumour part I-IV. Diagnosis of liver metastases could not be confirmed by first surgery but ${ }^{\star} 6$ months and +18 months later by second operation. EUS=endoscopic ultrasound; SRS=somatostatin receptor scintigraphy; CT=computed tomography; US=ultrasound; 
TABLE IV Sensitivities of various imaging procedures in the preoperative localisation of primary tumour lesions of insulinomas and gastrinomas

\begin{tabular}{lll}
\hline Imaging procedure & $\begin{array}{l}\text { Sensitivity } \\
\text { insulinomas (\%) }\end{array}$ & $\begin{array}{l}\text { Sensitivity } \\
\text { gastrinomas (\%) }\end{array}$ \\
\hline EUS & $13 / 14(93)$ & $11 / 14(79)$ \\
SRS & $2 / 14(14)$ & $12 / 14(86)$ \\
CT & $3 / 14(21)$ & $4 / 14(29)$ \\
US & $1 / 14(7)$ & $4 / 14(29)$ \\
MRI & $1 / 14(7)$ & $4 / 14(29)$ \\
\hline
\end{tabular}

EUS=Endoscopic ultrasound; $S R S=$ somatostatin receptor scintigraphy;CT=computed tomography; US=ultrasound; $M R I=$ magnetic resonance imaging.

Intraoperative ultrasonography was performed in all patients operated on. Duodenal transilluminations were done in all patients with gastrinoma. However, these two methods were not included for evaluation in our study protocol.

Endoscopic ultrasound examinations were carried out with echoendoscopes, using an ultrasound frequency of 7.5 or $12 \mathrm{MHz}$ and scanning in a plane perpendicular to the shaft axis of the endoscope (GF-UM 3/20, Olympus). The transabdominal ultrasound examinations were carried out with mechanical sector scanners and a sound frequency of 3.5 or $5 \mathrm{MHz}$ (LSC 7000, Picker). CT examinations were performed after oral and intravenous bolus contrast application (Somatom DRH, Siemens). The total abdomen was examined in $8 \mathrm{~mm}$ and the pancreatic region in $4 \mathrm{~mm}$ planes. Examinations with MRI were carried out with a 1.5 Tesla (Magnetom GBSII, Siemens) in $8 \mathrm{~mm}$ thick transverse sections using three pulse sequences. A T1 weighted (SE 500/15), a T2 weighted (SE $2 \cdot 300 / 90$ ) and a fast $T 1$ weighted (GRE $160 / 5 / 80^{\circ}$ ) spin echo sequence were used. The SRS examinations were carried out after an intravenous bolus of $100-200 \mathrm{Mbq}^{111} \mathrm{In}$ labelled pentetreotide (Octreoscan 111 Mallinckrodt-Diagnostica, Petten, Holland). Planar images were recorded with a large field view gammacamera (Orbiter 7500; Siemens, Erlangen, Germany) equipped with a $360 \mathrm{KeV}$ parallel hole collimator. All patients underwent anterior and posterior whole body static scintigraphy. Planar images were obtained four, 24, and in selected cases, 48 hours after injection of the radioligand. Single-photon emission computed tomography (SPECT) $\left(360^{\circ}\right.$ rotation in 32 minutes, matrix $\left.64 \times 64\right)$ was performed 24 hours after injection using a Sopha DS 7 camera (Sopha Medical, Frankfurt am Main, Germany) with a medium energy parallel hole general purpose collimator; images were reconstructed with filtered back projection and Chang correction in 6.7 $\mathrm{mm}$ slices. Digital (planar) images were analysed quantitatively by the region of interest method. Data were not corrected for transmission absorption or self attenuation. Liver uptake was calculated from the anterior view, and that of the spleen and kidneys were calculated from the posterior view. This technique has previously been described in detail. ${ }^{6} 26$

\section{Results}

GASTRINOMAS

A total of 14 separate primary tumour lesions were histologically confirmed in 10 patients (Table III). Nine tumours were situated in the pancreas (head $n=7$, body $n=1$, tail $n=1$ ), three in the duodenal wall, one in a periduodenal lymph node, and one in the liver (Table III). None of the patients with gastrinoma showed evidence of MEN I. Four patients had two gastrinoma lesions each. The mean tumour diameter was $2 \cdot 1 \mathrm{~cm}$. Four patients had a malignant tumour, with infiltration of the portal vein $(n=1)$, the superior mesenteric vein $(n=1)$, and liver metastases $(n=2)$ (Table III). Twelve of 14 tumours (sensitivity $86 \%$ ) could be visualised with SRS. Eleven of 14 tumours could be localised by EUS (sensitivity 79\%) and four of 13 by US (sensitivity $29 \%$ ) as well as by CT and MRI (Tables III and IV). A gastrinoma (4 cm in diameter) at the duodenojejunal flexure, a $2.4 \mathrm{~cm}$ tumour in the pancreatic head, and a $1.2 \mathrm{~cm}$ tumour in a periduodenal lymph node were not detected by EUS (Table III). The smallest tumours visualised by EUS were an $8 \mathrm{~mm}$ tumour of the duodenal wall and a $5 \mathrm{~mm}$ tumour in the pancreatic head (Table III). Ten of 14 gastrinoma lesions $(71 \%)$ were identified only by EUS and SRS (Table III). The tumours not detected by SRS were a $5 \mathrm{~mm}$ lesion situated

TABLE V Results of various imaging procedures in the preoperative localisation of insulinomas

\begin{tabular}{|c|c|c|c|c|c|c|c|c|}
\hline \multirow[t]{2}{*}{ Patient No } & \multirow{2}{*}{$\begin{array}{l}\text { Primary tumour } \\
\text { lesions }(n)\end{array}$} & \multirow{2}{*}{$\begin{array}{l}\text { Tumour } \\
\text { diameter }(\mathrm{cm})\end{array}$} & \multirow{2}{*}{$\begin{array}{l}\text { Tumour location within } \\
\text { the pancreas }\end{array}$} & \multicolumn{5}{|c|}{ Localisation of primary tumour by } \\
\hline & & & & EUS & SRS & $C T$ & US & $\overline{M R I}$ \\
\hline 1 & 1 & 2 & Tail & + & - & - & - & - \\
\hline 2 & 1 & 1.5 & Head & + & - & - & - & - \\
\hline \multirow[t]{5}{*}{3 (MEN I) } & 5 & 0.8 & Tail & - & - & - & - & - \\
\hline & & 1.5 & Tail & + & - & - & - & - \\
\hline & & 1.5 & Tail & + & - & - & - & - \\
\hline & & $2 \cdot 0$ & Tail & + & _- & - & - & - \\
\hline & & $2 \cdot 0$ & Tail & + & + & - & - & - \\
\hline 4 & 1 & 1.5 & Body & + & - & + & - & - \\
\hline $5^{\star}$ & 1 & $2 \cdot 0$ & Body & + & - & - & + & - \\
\hline $6+$ & 1 & 1.5 & Tail & + & - & + & - & - \\
\hline 7 & 1 & $1 \cdot 2$ & Body & + & - & - & - & - \\
\hline 8 & 1 & 1.5 & Body & + & - & _- & - & - \\
\hline 9 & 1 & $1 \cdot 3$ & Head & + & + & + & - & + \\
\hline 10 & 1 & $1 \cdot 4$ & Tail & + & - & - & - & - \\
\hline
\end{tabular}

*Tumour with infiltration of splenic vein and liver metastases confirmed by US guided biopsy; †Tumour with liver metastases ^Tumour with infiltration of splenic vein and liver metastases confirmed by US guided biopsy; $†$ Tumour with liver metastases guided by CT biopsy; tumour size with exception of patients 5 and 6 was determined by surgery; EUS=endoscopic ultrasoun
SRS=somatostatin receptor scintigraphy; $C T=$ computed tomography; US=ultrasound; MRI=magnetic resonance imaging. SRS=somatostatin receptor scintigraphy; CT
MEN I=multiple endocrine neoplasia type I. 
in the pancreatic head and a $1.2 \mathrm{~cm}$ periduodenal tumour (Table III).

The liver metastases in two patients were only correctly detected by SRS. In both patients, only SRS disclosed an increased local hepatic uptake of pentetreotide. These metastases could not be detected at the first operation by either surgical palpation or intraoperative ultrasound. However, postoperatively increasing gastrin values and positive secretin tests together with positive SRS findings led to second surgical interventions six and 18 months after the first operation. Intraoperative uiuasound and palpation confirmed the initial SRS findings in both patients. In one case, intraoperatively detected multiple $(>20)$ small $(<1 \mathrm{~cm})$ metastases in both liver lobes were not resectable. In the second case, two metastases of the left liver lobe were resected.

Intraoperatively, two patients showed tumours infiltrating the portal vein in one case and the superior mesenteric vein in the other (Table III). Preoperatively, these infiltrations could not be detected by any of the evaluated procedures or by angiography. A complete resection of the tumour was not achieved in either case.

Postoperatively, five patients had normalised fasting serum gastrin concentrations and a negative secretin test. Also, follow up by SRS, EUS, CT, MRI, and US showed no evidence of recurrence. Thus a curative resection was possible in five of 10 patients. Elevated fasting serum gastrin concentrations or a positive secretin test were found in the two patients with liver metastases as well as in two others with non-resectable pancreatic head tumours infiltrating the portal and superior mesenteric veins (Table III). In the patient with a solitary liver tumour, elevated gastrin concentrations were still found postoperatively. However, no other tumour lesions were found during the operation by either surgical palpation, intraoperative ultrasound, or duodenal transillumination.

The visualised duodenal tumours were endosonographically restricted to the middle hyperechoic layer (submucosal layer; Fig 1A). Endosonographically, eight of the 11 visualised gastrinomas displayed a hypoechoic (compared with the pancreas parenchyma), a homogeneous inner structure, and a smooth delineation (Fig 1B). Only three gastrinomas with a tumour diameter of more than $3 \mathrm{~cm}$ had an inhomogeneous, hyperechoic inner structure with hypoechoic to non-echoic parts and were irregularly demarcated. On SRS, gastrinoma lesions displayed a pronounced accumulation of radiolabelled somatostatin receptor ligand in all cases (Fig $1 \mathrm{C}$ ).

INSULINOMAS

Fourteen neuroendocrine tumour lesions were histologically verified in 10 patients thought to have an insulinoma (Table V). All tumours were intrapancreatic. The mean tumour diameter was $1.5 \mathrm{~cm}$. Two female patients had a malignant insulinoma with liver metastases. The primary lesion as well as the liver metastases of these two patients could be confirmed by biopsy. Angiography disclosed a primary tumour lesion infiltrating the splenic vein in one of these patients. In one patient with evidence of MEN I, five tumours were surgically confirmed (Table V).

The location of 13 of 14 tumours could be visualised using EUS (sensitivity 93\%). Only
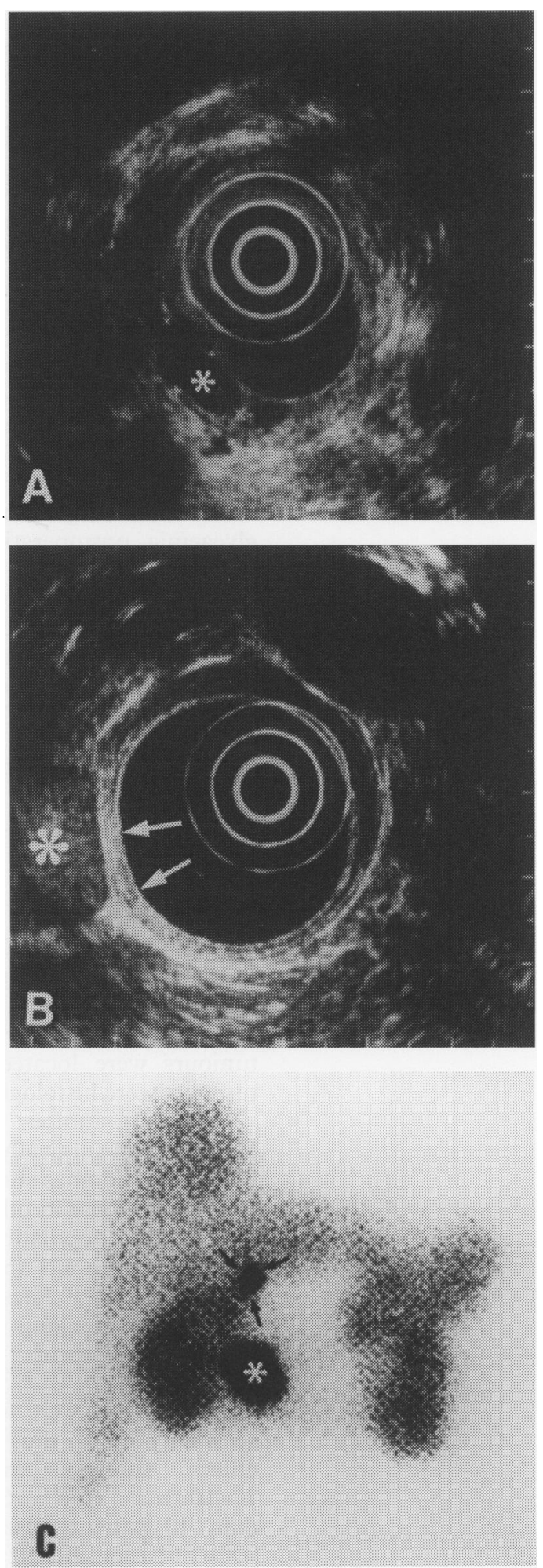

Figure 1: Multilocular gastrinoma of the pancreas and duodenal wall. Panel $A$ shows the endosonographic image of the duodenal tumour as a hypoechoic, smoothly demarcated mass about $8 \mathrm{~mm}$ in diameter $\left(^{\star}\right)$. Panel $B$ shows the endosonographic image of the pancreatic head tumour as a hypoechoic, smoothly demarcated mass about $2.5 \mathrm{~cm}$ in diameter ( ${ }^{*}$ ) near by the duodenal wall (arrows). Panel $C$ shows the somatostatin receptor scintigraphy with two hot spots projecting over the region of pancreatic head ( ${ }^{*}$ ) and duodenal bulb (arrows). 
two of 14 tumours could be localised by SRS (sensitivity $14 \%$ ), three of 14 by CT (sensitivity $21 \%$ ), one of 14 by US (sensitivity $7 \%$ ), and one of 14 by MRI (sensitivity 7\%) (Tables IV and V). Only one tumour, $8 \mathrm{~mm}$ in diameter, in a patient with MEN I, was not detected using EUS. This tumour was situated in the cranial part of the pancreatic tail (Table V). The other four tumour lesions of this patient, also located in the pancreatic tail, and an additional adenoma of the adrenal gland were clearly detected by EUS. Eight of 14 insulinoma lesions $(57 \%)$ could only be localised by EUS (Table V). The liver metastases confirmed in two female patients had been detected in both cases by CT, US, and MRI, in one case by SRS and in neither case by EUS. It is noteworthy that one patient with a positive scintigraphic finding of liver metastases had a negative SRS finding with regard to the intrapancreatic primary tumour. Additional infiltration of the splenic vein in one of the patients with liver metastases was detected by EUS and US but not by CT and MRI. The eight patients with insulinoma who underwent surgery no longer had hypoglycaemia postoperatively, and their fasting tests were normal.

Endosonographically, 11 of 13 visualised insulinomas displayed a hypoechoic (compared to the pancreas parenchyma), homogeneous inner structure and mostly a smooth delineation (Fig 2A). One of these 11 tumours, infiltrating the splenic vein, and two others in the patient with MEN I, were irregularly demarcated. Two other patients with benign insulinomas had hyperechoic tumours.

\section{Discussion}

This prospective study evaluated the accuracy of EUS and SRS compared with conventional imaging procedures in diagnosing insulinomas and gastrinomas. Most of the detected tumours were located in the pancreas. All tumours were histologically confirmed.

Regarding tumour size and location, our patients with surgically and histologically confirmed insulinomas showed no essential differences from those in other studies, whereas our gastrinoma population had fewer extrapancreatic tumours than the patients of previous studies. ${ }^{18}{ }^{19}$ These studies also examined the value of imaging procedures in the diagnostic assessment of insulinomas and gastrinomas. $^{3413192027}$

Gastrinomas were localised by SRS with a sensitivity of $86 \%$ thus confirming the results of other studies with sensitivities of $77-100 \% \%^{23} 25262829$ Studies including more than 40 patients also report sensitivities of $70 \%-80 \%$ for SRS. ${ }^{21} 24$ Apart from localising primary lesions, SRS is also extremely valuable for detecting further primary lesions and metastases, not disclosed by CT and US..$^{21} 26{ }^{30}$ The sensitivity of EUS for localisation of gastrinoma in our patients was $79 \%$, which was comparable to the sensitivity of $82 \%-100 \%$ found by others. ${ }^{16} 17$ Previous studies dealt almost exclusively with intrapancreatic gastrinomas. In
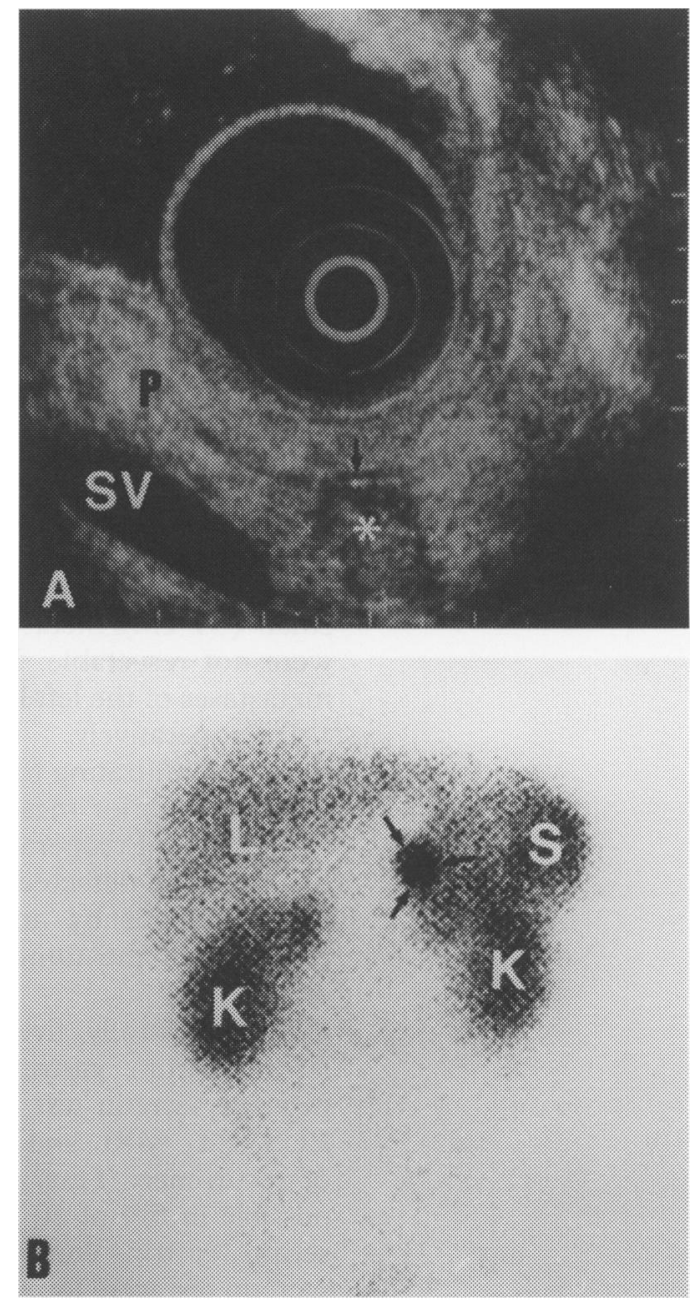

Figure 2: Insulinoma located in the tail of the pancreas. Panel $A$ shows the endosonographic image of the insulinoma as a hypoechoic tumour, about $10 \mathrm{~mm}$ in diameter ( $\left.{ }^{*}\right)$ immediately beside the main pancreatic duct (arrow). $P=$ pancreas, $S V=$ splenic vein. Panel $B$ shows the somatostatin receptor scintigraphy with a hot spot in the region of the tail of the pancreas (arrows). $L=$ liver, $K=$ kidneys, $S=$ spleen.

one study with a relatively high percentage of duodenal gastrinomas, EUS detected them with a sensitivity of only $50 \%$ alone but $60 \%$ combined with endoscopy. ${ }^{19}$ The high success rate in our own patient population is probably due to the high percentage of pancreatic gastrinomas. Combination of EUS and SRS detected 13 of 14 gastrinoma lesions (93\%). These results are comparable to those obtained by the use of portal venous sampling. ${ }^{9}$ There are no definitive results on the sensitivity of EUS and SRS in detecting gastrinomas with a diameter of less than $10 \mathrm{~mm}$, especially tumours in the area of the duodenal wall. The predominantly small duodenal gastrinomas could be intraoperatively visualised in about $60-90 \%$ by palpation, transduodenal illumination, and in all cases by direct exploration of the duodenum after duodenotomy. ${ }^{731}$ To exclude such small tumours, an exact surgical exploration of the duodenum, liver, and pancreas must be performed in combination with intraoperative ultrasound and duodenal transillumination. ${ }^{2}$ As expected, US, CT and MRI sensitivity in the localisation of gastrinomas was low, varying between $30 \%$ and $50 \%$ depending on the size and location. ${ }^{35616}$ In particular, tumours less 
than $2 \mathrm{~cm}$ in diameter and those located in the duodenal wall mostly remained undetected by US, CT, and MRI. ${ }^{6}$

The high sensitivity of EUS in the localisation of insulinomas confirmed the results of other studies reporting sensitivities of $77 \%-89 \% .^{14} 161720$ The sensitivity of EUS is thus comparable with that of more invasive procedures such as exploratory laparotomy with palpation and surgical ultrasound, which can correctly locate about $95 \%$ of occult insulinomas. ${ }^{32}$ EUS could thus play a special part in patients with MEN I, who often have multiple intrapancreatic tumours that are not detected by US, CT, or other invasive procedures. ${ }^{4}$ Although no additional pancreatic lesions were found by surgical palpation or intraoperative ultrasound in our patient with MEN I, we cannot exclude further very small tumours of the pancreatic head and body that escape detection by EUS and SRS.

By contrast to gastrinomas, insulinomas are less sensitively detected by SRS. So far, up to $50 \%$ of all insulinomas were detected by SRS. ${ }^{24}$ We have found SRS to be even less sensitive than previously reported. This can be explained by the smaller sized tumours investigated as well as by the relatively low amount of ${ }^{111}$ In-pentetreotide applied. ${ }^{22-25} \mathrm{~A}$ recent study showed a sensitivity of $53 \%$ for SRS in 47 patients with insulinoma. ${ }^{24}$ In this study, however, $71 \%$ of all patients had tumours already detectable by conventional imaging modalities, indicating the presence of large tumours. In our study, on the other hand, patients with insulinomas could be diagnosed by conventional imaging modalities in only $29 \%$ of all cases. ${ }^{24} \mathrm{~A}$ lower tumour diameter is thus the main factor explaining the low sensitivity in our study. Other factors which negatively influence sensitivity might be the short counting time per projection and viewing field as well as the use of a one headed instead of a more sensitive three headed camera. ${ }^{24}$ Better results can be expected in the future through computer assisted three dimensional assessments and somatostatin analogues with other receptor subtype specificity. ${ }^{33} 34$ Insulinomas are known to express individual subtypes of somatostatin receptors which do not bind to pentetreotide. ${ }^{33}$ Current studies by our group show that tumours with negative SRS results likewise do not bind to pentetreotide in vitro. Furthermore, insulinomas seem to express mainly somatostatin receptor subtypes 1 and 4 which escape pentetreotide binding. ${ }^{35}$ Thus use of appropriate analogues should enable the future detection of even small tumours with different receptor density and subtypes. So far, however, no such analogues are available for in vivo imaging.

In summary, our data show that EUS has the highest sensitivity for both tumour entities, whereas SRS has a comparable sensitivity only in the case of gastrinomas. On the other hand CT, US, and MRI are good imaging procedures only for the determination of metastatic spread.

For gastrinomas, SRS and EUS represent the methods of choice for preoperative diag- nosis. A combination of both methods achieves a reliability comparable with that of invasive operative procedures for the identification of both primary and secondary lesions. SRS has a direct therapeutic impact because it is able to detect metastases equally well. To exclude small gastrinomas in the duodenal wall or peripancreatic lymph nodes, intraoperative ultrasound and duodenal transillumination should always be performed as well as palpation during surgery.

The most sensitive diagnostic procedure for insulinomas was EUS. Here SRS is even less sensitive than US, CT, and MRI.

The use of US, CT, and MRI remains limited mainly to the identification of enlarged lymph nodes and liver metastases.

We thank Professor Dr K von Werder and Dr M Zschiedrich, Department of Internal Medicine, Schlossparkklinik, Berlin, Professor Dr H-J Quabbe, Dr U Plöckinger and Dr J Schwander, Department of Internal Medicine and Endocrinology, Klinikum Benjamin Franklin, Berlin, for their cooperation and Professor J F Rehfeld for critical reading of the manuscript.

1 Broughan TA, Leslie JD, Soto JM, Hermann RE. Pancreatic islet cell tumors. Surgery 1986; 99: 671-8.

2 Fraker DL, Norton JA. The role of surgery in the management of islet cell tumors. In: Jensen RT, ed. Gastrointestinal endocrinology. Gastroenterol Clin North Am 1989; 18: 805-30.

3 Frucht HF, Doppman JL, Norton JA, Miller DL, Dwyer AJ, Frank JA, et al. Gastrinomas: Comparison of MR imaging with CT, Angiography, and US. Radiology 1989; 171: 713-7.

4 Galiber AK, Reading CC, Charboneau JW, Sheedy PF, James EM, Gorman B, et al. Localization of panceatic insulinoma: Comparison of pre- and intraoperative US with CT and angiography. Radiology 1988; 166: 405-8.

5 Wank SA, Doppman JL, Miller DL, Collen MJ, Maton PN, Vinayek R, et al. Prospective study of the ability of computed axial tomography to localize gastrinomas in patients with Zollinger-Ellison syndrome. Gastroenterology 1987; 92: 905-12.

6 Zimmer T, Ziegler K, Bäder M, Fett U, Hamm B, Riecken EO, Wiedenmann B. Localisation of neuroendocrine tumours of the upper gastrointestinal tract. Gut 1994; 35: 471-5

7 Frucht HF, Norton JA, London JF, Vinayek R, Doppman JL, Gardner JD, et al. Detection of duodenal gastrinomas by operative endoscopic transillumination. Gastroenterology 1990; 99: 1622-7.

8 Hemmingsson A, Lindgren PG, Lörelius LE, Öberg K. Diagnosis of endocrine gastrointestinal tumours. Acta Radiol Diagn 1981; 22: 657-61.

9 Krudy AG, Doppman JL, Jensen RT, Norton JA, Collen MJ, Shawker TH, et al. Localization of islet cell tumors by dynamic CT. Comparison with plain CT, tumors by dynamic CT. Comparison with plain $\mathrm{CT}$,
arteriography, sonography, and venous sampling. $A m \mathcal{F}$ arteriography, sonography, and

10 Roche A, Raisonnier A, Gillon-Savouret MC. Pancreatic venous sampling and arteriography in localizing insulinomas and gastrinomas: procedure and results in 55 cases. Radiology 1982; 145: 621-7.

11 Delvalle J, Yamada T. Secretory tumors of the pancreas. In: Sleisinger MH, Fordtran JS, eds. Gastrointestinal disease: pathophysiology, diagnosis, management. 4th ed. Philadelphia: WB Saunders, 1989: 1884-1900.

12 Ellison EH, Wilson SD. The Zollinger-Ellison syndrome: re-appraisal and evaluation of 260 registered cases. Ann Surg 1964; 160: 512-530.

13 Pipeleers-Marichal M, Somers G, Willems G, Foulis A, Imrie C, Bishop AE, et al. Gastrinomas in the duodenum of patients with multiple endocrine neoplasia type 1 and of patients with multiple endocrine neoplasia type 1 and
the Zollinger-Ellison syndrome. N Engl f Med 1990; 322: the Zollinge

14 Glover JR, Shorvon PJ, Lees WR. Endoscopic ultrasound for localisation of islet cell tumours. Gut 1992; 33: 108-10.

15 Lightdale CJ, Botet JF, Woodruff JM, Brennan $M$. Localization of endocrine tumors of the pancreas with endoscopic ultrasonography. Cancer 1991; 68: 1815-20.

16 Palazzo L, Roseau G, Salmeron M. Endoscopic ultrasonography in the preoperative localization of pancreatic endocrine tumors. Endoscopy 1992; 24 (suppl 1): 350-3.

17 Rösch T, Lightdale CJ, Botet JF, Boyce GA, Sivak MV, Yasuda $\mathrm{K}$, et al. Localization of pancreatic endocrine tumors by endoscopic ultrasonography. $N$ Engl $₹ \mathrm{Med}$ 1992; 326: 1721-6.

18 Thompson NW, Czako PF, Fritts LL, Bude R, Bansal R, Nostrant TT, Scheiman JM. Role of endoscopic ultrasonography in the localization of insulinomas and gonography in the localization of in

19 Ruszniewski P, Amouyal P, Amouyal G, Grange J-D, Mignon M, Bouche O, Bernades P. Localization of 
gastrinomas by endoscopic ultrasonography in patients with Zollinger-Ellison syndrome. Surgery 1995; 117: 629-35.

20 Ruszniewski P, Amouyal P, Amouyal G, Cadiot G, Mignon M, Bernardes P. Endocrine tumors of the pancreatic area: localization by endoscopic ultrasonography. In: Mignon M, Jensen RT, eds. Endocrine tumors of the pancreas. Frontiers in gastronintestinal research. Basel, Karger 1995; 23: 258-67.

21 de KervilerE, Cadiot G, Lebtahi R, FaraggiM,LeGuludecD, Mignon M. Somatostatin receptor scintigraphy in fortyeight patients with the Zollinger-Ellison syndrome. Eur $\mathcal{F}$ Nucl Med 1994; 21: 1191-7.

22 Krenning EP, Bakker WH, Breeman WAP, Koper JW, Kooij PPM, Ausema L, et al. Localisation of endocrinerelated tumours with radioiodinated analogue of rematostatin. Lancet 1989; I: 242-4.

23 Krenning EP, Kwekkeboom DJ, Reubi JC, van Haagen PM, van Eijck CJH, Oei HY, Lamberts SWJ. ${ }^{111}$ In-Octreotide scintigraphy in oncology. Metabolism 1992; 41: 83-6.

24 Krenning EP, Kwekkeboom DJ, Oei HY, de Jong RJB, Dop JF, Reubi JC, Lamberts SWJ. Somatostatin receptor scintigraphy in gastroenteropancreatic tumors: an overview of European results. Ann NY Acad Sci 1994; 33: 416-24.

25 Lamberts SWJ, Bakker WH, Reubi JC, Krenning EP. Somatostatin receptor imaging in the localization of endocrine tumors. N Engl f Med 1990; 323: 1246-9.

26 Scherübl H, Bäder M, Fett U, Hamm B, Schmidt-Gayk R, Koppenhagen $\mathrm{K}$, et al. Somatostatin-receptor imaging of neuroendocrine gastroenteropancreatic tumors. Gastroenterology 1993; 105: 1705-9.

27 Stark DD, Moss AA, Goldberg HJ, Deveney CW. CT of pancreatic islet cell tumors. Radiology 1984; 150: 491-4.

28 Höring G, Räth U, Rücker S, Gaisberg U, Meincke J, Walendzik J, et al. Somatostatinrezeptor-Szintigraphie in der Primärdiagnostik und Nachsorge bei Gastrinomen. Dtsch med Wochenschr 1994; 119: 367-74.

29 Jamar F, Fiasse R, Leners N, Pauwels SF. Somatostatin receptor imaging with Indium-111-pentetreotide in gastroenteropancreatic neuroendocrine tumors: safety, efficacy and impact on patients management. $\mathcal{F}$ Nucl Med 1995; 36: 542-9.

30 Joseph, K, Stapp J, Reinecke J, Höffken H, Benning R, Neuhaus C, et al. Rezeptorszintigraphie bei endokrinen gastroenteropankreatischen Tumoren. Disch med Wochenschr 1992; 117: 1025-8.

31 Sugg SL, Norton JA, Fraker DL, Metz DC, Pisegna JR, Fishbeyn $\mathrm{V}$, et al. A prospective study of intraoperative methods to diagnose and resect duodenal gastrinomas. Ann Surg 1993; 218: 138-44.

32 van Heerden JA, Grant CS, Czako PF, Service FJ, Charboneau JW. Occult functioning insulinomas: which localizing studies are indicated? Surgery 1992; 112: 1010-5.

33 Lamberts SWJ, Hofland LJ, van Koetsveld PM, Reubi JC, Bruining HA, Bakker WH, Krenning EC. Parallel in vivo and in vitro detection of functional somatostatin receptors in human endocrine pancreatic tumors: consequences with regard to diagnosis, localization, and therapy. $f$ Clin Endocrinol Metab 1990; 71: 566-74.

34 Westlin JE Ahlström $\mathrm{H}$, Yla-Jääski J, Öberg K, Nilson S. Three-dimensional octreoscan 111 SPECT of abdominal manifestation of neuroendocrine tumours. Acta Oncol 1992; 32: 171-6.

35 John M, Meyerhof W, Richter D, Waser B, Schaer J-C, Scherübl $\mathrm{H}$, et al. Positive somatostatin receptor scintigraphy correlates with the presence of somatostatin receptor subtype 2. Gut 1996; 38: 33-9. Erratum: Positive somatostatin receptor scintigraphy correlates with the presence of somatostatin receptor subtype 2 and 5 . Gut 1996; 38: 302 . 